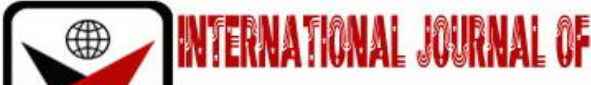

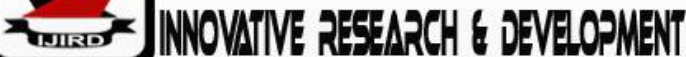

ISSN 2278 - 0211 (Online)

\section{The Role of Women in Domestic Solid Waste Management in Adamawa State, Nigeria}

\begin{tabular}{|c|}
\hline Dr. Onyemelukwe S.o. \\
Lecturer, Department of Geography and Environmental Management, \\
Ahmadu Bello University, Nigeria \\
Sawa O.A. \\
Deputy Registrar, Department of Registry, \\
Federal College of Education Yola, Nigeria \\
George I.I \\
Ph. D. Student, Ahmadu Bello University, Nigeria \\
Suleiman S. \\
Lecturer, Department of Geography, Federal College of Education, Nigeria
\end{tabular}

\section{Abstract:}

This is focused on the analysis of women's role in domestic waste management in Adamwa State, Nigeria with a view to recognizing their roles as well as incorporating their suggestions in matters relating to waste management in particular and environmental issues in general in order to provide sound knowledge base for effective waste management policy framework in the State. Data was collected from a questionnaire survey sample of 400 women residents in Adamawa State. The study reveals that mothers/wives dominated other members of households mostly involved home based activities that results in waste generation such sweeping, washing/cleaning and cooking as shown in the order of 50.0\%, $55.8 \%$ and $75.0 \%$. Also, children especially the females with 40.0\% dominated other household members on waste disposal, while the male heads with (57.0\%) compared to wives with $43.0 \%$ are more involved in offsetting the bills for waste disposal. Analysis of women's activities in the last 6 months shows that majority of the women (65.0\%) have changed their ways in order to reduce the amount of household waste generation. Also majority $60.0 \%$ and $76.2 \%$ have participated in monthly sanitation programme and cleared a refuse site around their houses respectively. The finding is a clear indication that most women are environmentally conscious, hence ready to physically contribute towards ensuring hygienic environment. Organic type of waste dominated with $47.5 \%$ on household waste generation, while inorganic waste constitutes $40.0 \%$ of waste household waste materials. Majority of an average household in the study area generates between $3 \mathrm{~kg}$ and $4 \mathrm{~kg}$ of waste daily. Large percentage of the sampled women (61\%) does not sort their waste before disposing. Burying of wastes in landfills pits with 25.8 dominated the preferred waste disposal methods by the women. Vast majority of respondents (55.8\%) dump their wastes in non-secured dump sites, whereas about 74.5\% preferred to dispose their wastes in secured dump site. Majority of the women (40.8\%) indicated low frequency of service as their main concerns from the services of waste management authorities, followed by lack of clean appearance around the bin after collection of wastes by the waste collectors with $23.6 \%$. It is therefore recommended that for there to be an effective waste management programmes and services, women should be strongly involved in solidarity networks, where they seek collective solutions for improving the environment. They should be found at the root of every initiative relating to health care, supply of drinking water or awareness about environmental sanitation in the State in general.

Keywords: Domestic waste, dump site, waste management, waste sorting, household

\section{Introduction}

Domestic wastes are related to human living activities and originate from residential areas, that is, they are wastes generated from the homes and households in the process of carrying out domestic activities like cooking, sweeping, general sanitary activities etc. Also Business Dictionary (2014) views Domestic Solid waste as wastes comprising of garbage and rubbish (such as bottles, cans, clothing, compost, disposables, foodpackaging, food scraps, newspapers and magazines, and yard trimmings) that originates from private homes or apartments.

Studies have shown that domestic/household waste constitutes about 40 - 60\% of urban waste (Benneh, Songsore, Nabila, Amuzu and Tutu, 1993); with the composition mostly dependent on food habits, collection of recyclable materials, the resident's wealth, in-house composting and climate conditions (Imam, Mohammed, Wilson and Cheeseman,2007); and is often one of the most difficult sources of solid waste to manage because of its diverse range of composite materials, which are hardly sorted out prior to disposal (Onu, Price, Surendra and Ebie, 2001). 
In many parts of Adamawa State, management of environmental sanitation and hygiene practice is a cumbersome process because of attitudinal problems. This stems from the perception that environmental sanitation and hygiene related matters are of a lower-order priority than most other social issues (Enweze, 2000); as well as due to the lack of understanding of the vital roles of women towards waste management issues, more importantly within the household where most domestic waste are generated. To address waste management problems more effectively, there is the need to have an understanding of women contributions to waste management issues especially on domestic wastes which constitutes one of the greatest proportions of waste sources anywhere in the world (Ahmed, 2007).

In furtherance, Ogunboye (2003) observed that the inability to recognize the crucial role of women in the management processes and programmes in the society results to wastages. To buttress the above, Willson (2007) in a gender related study equipped that a wide range of development programmes and projects that involved women were successfully implemented. Despite these submissions, urban managers in the developing countries are yet to accept women as active actors instead of victims and passive objects on which various approaches to women and development are being applied. It is time to realize that if projects are to be effectively implemented and managed properly in any given society, it is essential to identify and to integrate the roles of women in urban environmental management, especially in the aspect of sustaining environmental quality and in terms of waste management (Moser, 1993). The fact that men and women often play different roles in the society suggests that we should start to recognize the need and importance of disaggregating environmental issues on the basis of gender. In Africa, women have been in the frontline of most household socio-economic activities. Throughout the history of human civilization, the roles of women are particularly pronounced in domestic activities.

For instance, women's perspectives and values for the environment according to Jiggins (1994) are somewhat different from those of men. Women give greater priority to the protection of and improving the capacity of nature, maintaining farming lands, and caring for nature. Dankelman and Davidson (1998) observed that women play a key role in managing their natural surroundings and adopt several mechanisms to deal with the kinds of environmental crisis they face. Studies have shown that eventually, women are generally responsible for human waste disposal of children and cleanliness of latrines and other facilities (Akwa, 2009). It is observed that women are usually associated with the responsibility for cleanliness of the domestic environment and for the health of the family. In addition, Conserve Africa (2013) relates that in Africa women are primary resource users, their responsibilities and activities are directly on landbased resources as well as maintained that women produce $80 \%$ of the basic food commodities in Africa.

From the above foregoing, one cannot afford to lose sight of the pivotal role that women command in the web of debates on sustainability of the natural resources and human habitat. In a nutshell, it means that taking care of the environmental resources and human settlements is not a new challenge to the womenfolk who have been the home managers since the beginning of time. But modernity has brought a new challenge into environmental management with several dimensions for women. The report of the United Nations, fourth world conference on women (1995) indicated that men often are less concerned about general environmental maintenance unlike the women, as men often pursue work in distant locations, leaving women to safeguard the natural environment and ensure adequate and sustainable resource allocation within the household and the community.

Given the above, there is a need to investigate the applicability and replicability of these issues in the study area especially with regards to waste management. This is because, socio-culturally, women differ in the environmental appreciation and ecological aesthetics which ultimately affects their waste management endeavours. Women are closely linked with waste generation, but their concern for management of waste as well as methods adopted is not clearly understood. Therefore, given the availability of multiple options for management, the effort of women in waste generation and transfer of waste from house to dumpsite and final destination points need to be adequately investigated.

Therefore, it is in recognition of these facts that this research examined the roles of women in domestic solid waste management in Adamawa State. To achieve this, the following objectives were explored;

- Examine the level of women involvement in waste management.

- Assess the domestic waste generation and disposal processes

- Identify the challenges of women in domestic waste management.

\section{Study Area}

Adamawa state is located at the north eastern part of Nigeria around the area where the River Benue enters Nigeria from the Cameroun Republic. It lies between latitude $7^{\circ} 30^{\prime \prime} \mathrm{N}-10^{\circ} 40^{\prime \prime} \mathrm{N}$ and longitude $11^{\circ} 15^{\prime \prime} \mathrm{E}-13^{\circ} 40^{\prime \prime} \mathrm{E}$ of the Greenwich Meridian. The state shared boundaries with Taraba State in the south, Bauchi to its north-west Yobe and Borno States to the north. Adamawa State has an International boundary with Cameroun Republic along its eastern side and covers a land area of about 39,742.13ksq/cm. According to NPC (2006) report, the State has a population of 3,178,950 and the dominant economic activities ranges from food and cash crop production, livestock production to traditional and manufacturing industries. Agricultural activities are the predominant economic activities in the State, whereas, manufacturing industries are unevenly distributed across the State with significant concentration in Yola the State capital. 


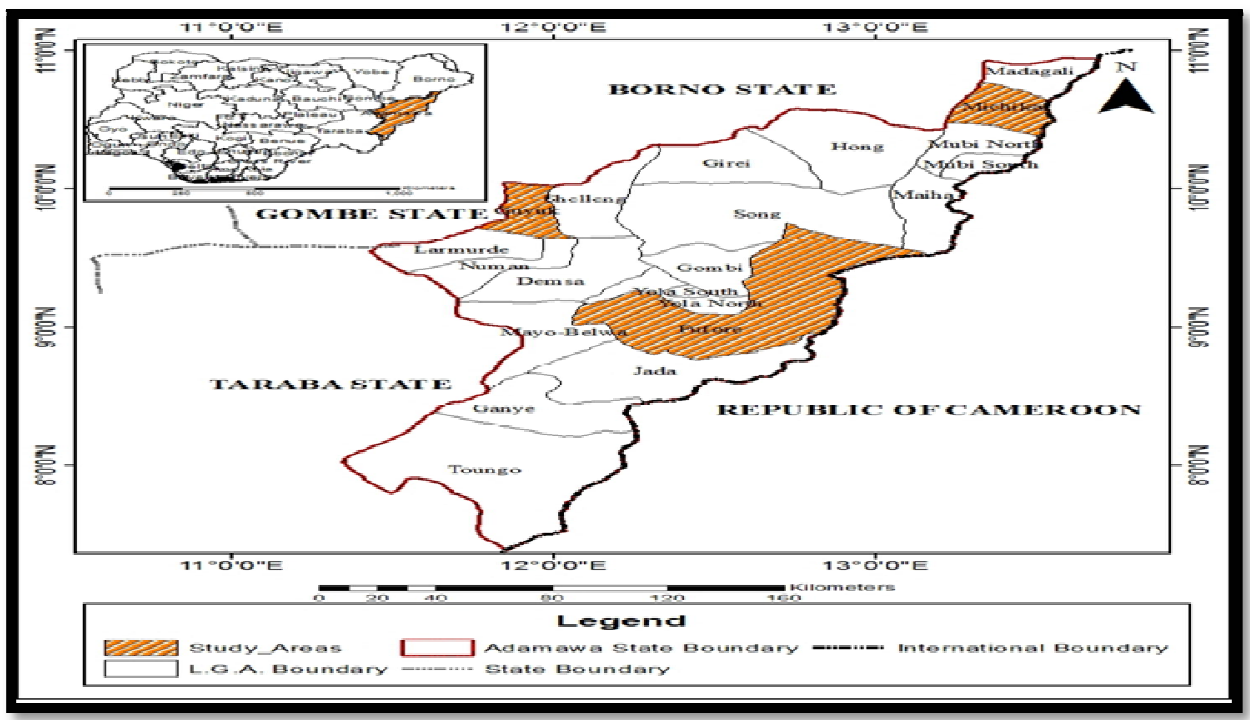

Figure 1: Adamawa State Showing the Study Locations Source: Modified from Administrative Map of Adamawa State (2010)

\section{Materials and Methods}

\subsection{Reconnaissance Survey}

A reconnaissance survey was conducted so as to be well acquainted with the study areas and to properly identify the settlements to be surveyed.

Both primary and secondary types of data were utilized in this study. The primary data used in this research was sourced from first-hand information derived through observations, questionnaire administration and oral interviews. The data include, but not limited to; socio-economic characteristics of the respondents, types and quantities of household wastes generation as well as the methods of disposal. Similarly, the secondary information were sourced from books, Journals, published and unpublished texts, documents, magazines, conference articles, government ministries, agencies and parastatals.

\subsection{Sampling Design and Questionnaire Administration}

In order to select respondents for the questionnaire administration, three (3) LGAs was selected. i.e. one from each of the three senatorial districts of north, central and southern districts. The selection of the LGAs were based on the ones LGA with the highest housing population in each senatorial district (i.e. Michika, Fufore and Guyuk). Moreso, this it is generally known that waste management practices and waste management infrastructure provision differs significantly by types of settlements. A stratified random sampling technique was used, where the headquarters of each selected LGAs was sampled as an urban centers whereas, one rural community was randomly selected therein and sampled as a rural center. This was done so as to address the possible differentials both in management and practiceson waste related issues between rural and urban dwellers. Also, to avoid biasness in questionnaire administration, copies of questionnaire was purposively administered to each selected households (See Table 1).In each household which was randomly selected, questionnaires were administered to the female adult. This was done to ensure that effective and valid responses are gathered from each household, since every household generates and manages its wastes separately and differently.

\begin{tabular}{|c|c|c|c|c|c|c|c|}
\hline $\begin{array}{c}\text { Senatorial } \\
\text { Zones }\end{array}$ & $\begin{array}{l}\text { Adamawa } \\
\text { State LGA }\end{array}$ & $\begin{array}{l}\text { Selected } \\
\text { L.G.A }\end{array}$ & $\begin{array}{l}2006 \text { Pop } \\
\text { Census }\end{array}$ & $\begin{array}{c}2006 \\
\text { Household } \\
\text { Pop Census }\end{array}$ & $\begin{array}{c}\text { Total } \\
\text { Sampled } \\
\text { households }\end{array}$ & $\begin{array}{c}\text { Sampled } \\
\text { Settlement }\end{array}$ & $\begin{array}{c}\text { Total } \\
\text { Samples }\end{array}$ \\
\hline \multirow{5}{*}{$\begin{array}{l}\text { Adamawa } \\
\text { North }\end{array}$} & Madagali & & 135,142 & 24,942 & & Bazza (HQrt) & 58 \\
\hline & Maiha & & 110,175 & 18,940 & & & \\
\hline & Michika & Michika & 155,238 & 28,734 & 116 & & \\
\hline & Mubi North & & 151,515 & 26,166 & & & \\
\hline & Mubi South & & 129,956 & 22,548 & & Wutu & 58 \\
\hline \multirow{7}{*}{$\begin{array}{c}\text { Adamawa } \\
\text { Central }\end{array}$} & Fufore & Fufore & 209,460 & 36,818 & 148 & Mayo-in (HQrt) & 74 \\
\hline & Girei & & 129,855 & 23,208 & & & \\
\hline & Gombi & & 147,787 & 26,618 & & & \\
\hline & Hong & & 169,183 & 30,657 & & & \\
\hline & Song & & 195,188 & 34,319 & & & \\
\hline & Yola North & & 199,674 & 34,907 & & & \\
\hline & Yola South & & 196,197 & 34,918 & & & \\
\hline
\end{tabular}




\begin{tabular}{|c|c|c|c|c|c|c|c|}
\hline $\begin{array}{c}\text { Senatorial } \\
\text { Zones }\end{array}$ & $\begin{array}{c}\text { Adamawa } \\
\text { State LGA }\end{array}$ & $\begin{array}{l}\text { Selected } \\
\text { L.G.A }\end{array}$ & $\begin{array}{l}2006 \text { Pop } \\
\text { Census }\end{array}$ & $\begin{array}{c}2006 \\
\text { Household } \\
\text { Pop Census } \\
\end{array}$ & $\begin{array}{c}\text { Total } \\
\text { Sampled } \\
\text { households }\end{array}$ & $\begin{array}{c}\text { Sampled } \\
\text { Settlement }\end{array}$ & $\begin{array}{c}\text { Total } \\
\text { Samples }\end{array}$ \\
\hline \multirow{9}{*}{$\begin{array}{l}\text { Adamawa } \\
\text { South }\end{array}$} & Demsa & & 178,407 & 33,231 & & & \\
\hline & Ganye & & 169,948 & 29,552 & & Wuro-Sam & 74 \\
\hline & Guyuk & Guyuk & 176,505 & 33,601 & 136 & Banjiram (HQrt) & 68 \\
\hline & Jada & & 168,445 & 30,715 & & & \\
\hline & Lamurde & & 111,254 & 20,898 & & & \\
\hline & Mayobelwa & & 152,803 & 28,982 & & & \\
\hline & Numan & & 91,549 & 19,047 & & & \\
\hline & Shelleng & & 148,490 & 28,182 & & & \\
\hline & Toungo & & 52,179 & 9,365 & & Wawi & 68 \\
\hline & \multicolumn{2}{|c|}{ Adamawa state } & $3,178,950$ & 576,348 & 400 & & 400 \\
\hline
\end{tabular}

Table 1: Population and Percentages of LGAs for Questionnaire Administration

Source: NPC (2006)

\section{Results and Discussion}

\subsection{Levels of Women Involvement in Waste Management}

\subsubsection{Specific Household Daily Activities}

Table 2 indicates that mothers/wives dominated other members of the family mostly involved household activities that results in waste generation such sweeping, washing/cleaning and cooking as shown in the order of 50.0\%, $55.8 \%$ and $75.0 \%$. This is followed closely by female children that constitute $17.5 \%, 12.4 \%$ and $5.0 \%$ among those that are involved in sweeping, washing/cleaning and cooking accordingly. This further confirmed by Chuwang (1997) reported that sex and age are the main determining factors in household refuse handling, Chuwang, further asserted that women and girls gather, store and evacuate the refuse in the household, a responsibility which he attributed to African culture irrespective of income level.

\begin{tabular}{|c|c|c|c|c|c|c|c|c|c|c|}
\hline $\begin{array}{c}\text { Membership of } \\
\text { Household }\end{array}$ & \multicolumn{3}{|c|}{ Sweeping } & \multicolumn{2}{c|}{$\begin{array}{c}\text { Washing/ } \\
\text { Cleaning }\end{array}$} & \multicolumn{2}{c|}{ Cooking } & \multicolumn{2}{c|}{$\begin{array}{c}\text { Waste } \\
\text { Disposal }\end{array}$} & \multicolumn{2}{c|}{$\begin{array}{c}\text { Payment for } \\
\text { Waste Disposal }\end{array}$} \\
\hline & No. & $\mathbf{\%}$ & No. & $\%$ & No. & \% & No. & \% & No. & \% \\
\hline Father/Husband & 08 & 2.0 & 12 & 3.0 & 20 & 5.0 & 10 & 2.5 & 106 & 57.0 \\
\hline Mother/Wife & 200 & 50.0 & 223 & 55.8 & 300 & 75.0 & 95 & 23.8 & 80 & 43.0 \\
\hline Male Children & 42 & 10.5 & 40 & 10 & 10 & 2.5 & 110 & 27.5 & - & \\
\hline Female Children & 70 & 17.5 & 50 & 12.4 & 20 & 5.0 & 160 & 40.0 & - & \\
\hline Any Body & 60 & 15.0 & 75 & 18.8 & 50 & 12.5 & 25 & 6.2 & - & \\
\hline Total & 400 & 100 & 400 & 100 & 400 & 100 & 400 & 100 & 186 & 100 \\
\hline
\end{tabular}

Table 2: Distribution of Household Daily Activities Resulting to Waste Generation, Management, Disposal and Payment by Members of Households

Again in terms of household waste storage and disposal activities, female children constitute the majority with $40.0 \%$, followed by the male children with $27.5 \%$. Among the heads of households, wives with $23.8 \%$ outnumbered the husbands with $2.5 \%$ among those involved in waste disposal activities. The reasons for children outnumbering other members of the households in waste disposal activities may not be far-fetched as this may likely be due to the fact that within the traditional African society, children are often times responsible for running errand within and outside the domestic environments. By implication, the decision of who disposes the household waste within the family is very important as it will assist waste managers in designing suitable disposal sites for effective waste management system, as experience has shown that the siting of unsuitable waste disposal system either makes it too high for children to reach the sides and perhaps too far for some women to travel to which results in the dumping of waste next to the skips, Blight and Mbande (1994). Lastly, husbands constitutes majority (57.0\%), compared to wives with $43.0 \%$ among household members responsible for waste disposal service payment. This is a reflection of a patriarchal society where husbands are often seen as the breadwinners of the family more especially in the aspect of assuming the position as the financial backbone of the family.

\subsection{Participated Environmental Concerned Activities in the Last Six Months}

Table 3 shows the type of activities participated in by the women in the last 6 months with regards to environmental concerns. The result shows that majority of the women $(65.0 \%)$ have changed their ways in order to reduce the amount of household waste generation. Also majority $60.0 \%$ and $76.2 \%$ have participated in monthly 
sanitation programme and cleared a refuse site around their houses respectively. The finding is a clear indication that most women are environmentally conscious, hence ready to physically contribute towards ensuring hygienic environment.

\begin{tabular}{|c|c|c|c|c|c|c|}
\hline \multirow{2}{*}{ Responses } & \multicolumn{2}{|c|}{ Yes } & \multicolumn{2}{c|}{ No } & \multicolumn{2}{c|}{ Total } \\
\cline { 2 - 7 } & No. & \% & No. & \% & No. & $\%$ \\
\hline $\begin{array}{c}\text { Changed your ways in order to reduce the } \\
\text { amount of waste generated in the home }\end{array}$ & 260 & 65.0 & 140 & 35.0 & 400 & 100 \\
\hline $\begin{array}{c}\text { Participated in waste management activities in } \\
\text { the environment }\end{array}$ & 180 & 45.0 & 220 & 55.0 & 400 & 100 \\
\hline $\begin{array}{c}\text { Supported the development of environmental } \\
\text { policy of your area }\end{array}$ & 100 & 25.0 & 300 & 75.0 & 400 & 100 \\
\hline $\begin{array}{c}\text { Attended trainings, seminars or workshops on } \\
\text { environmental education/management }\end{array}$ & 70 & 17.5 & 330 & 82.5 & 400 & 100 \\
\hline $\begin{array}{c}\text { Decided to reuse or recycle something rather } \\
\text { than throw them away }\end{array}$ & 120 & 30.0 & 280 & 70.0 & 400 & 100 \\
\hline $\begin{array}{c}\text { Reduced waste generation for environmental } \\
\text { reasons }\end{array}$ & 190 & 47.5 & 210 & 52.5 & 400 & 100 \\
\hline $\begin{array}{c}\text { Contributed to an organization that works to } \\
\text { protect the environment }\end{array}$ & 150 & 37.5 & 250 & 62.5 & 400 & 100 \\
\hline Participated in a monthly sanitation programme & 240 & 60.0 & 160 & 40.0 & 400 & 100 \\
\hline Discouraged burning of refuse & 50 & 12.5 & 350 & 87.5 & 400 & 100 \\
\hline Cleared a refuse site around the house & 305 & 76.2 & 95 & 23.8 & 400 & 100 \\
\hline
\end{tabular}

Table 3: Respondents Activities in the Last 6 Months to Improve the Environment

Conversely, most of the respondents $82.5 \%$ and $87.5 \%$ have neither participated in trainings, seminars or workshops on environmental education nor discouraged burning of refuse within their areas. This may be due largely to non-existence of such forum like training/seminars programmes within their areas as well as unavailability of an alternative ways to dispose of their wastes, hence resort to the convenient option of burning or open dump system of wastes disposal. Generally, it is crystal clear that women in the study areas have concerns towards improving the conditions of their immediate environments. This is shown from the list of activities they have carried out in the last 6 months in their various localities.

\subsection{Domestic Waste Generation and Disposal Processes}

\subsubsection{Types of waste Generated within the Household}

Table 4 summarizes the type/composition of wastes generated by the respondents. In all, about $47.5 \%$ of the respondents generate mainly organic waste within their household, while $40.0 \%$ generates mainly inorganic materials.

\begin{tabular}{|c|c|c|}
\hline Type of Waste Generated & Frequency & Percentage \\
\hline Mainly organic waste & 190 & 47.5 \\
\hline Mainly inorganic waste & 160 & 40.0 \\
\hline Others & 50 & 12.5 \\
\hline Total & 400 & 100.0 \\
\hline
\end{tabular}

Table 4: Distribution of Respondents on Types of Waste Generated within the Household

Others category of wastes such as combinations of both organic and inorganic wastes make up 12.5\%. The dominance of organic waste as the major type of waste generated in the area is a not unexpected as most of the wastes are food residue. As it is noted by Iman et al (2007) that the ccompositions of household solid wastes depends on food habits, collection of recyclable materials, the resident's wealth, in-house composting and climate conditions.

\subsection{Quantity of Waste Generated Daily}

Table 5 shows the quantity of waste generated by respondents on daily basis. It shows from the data that majority of the respondents (50.0\%) generate between $3 \mathrm{~kg}$ and $4 \mathrm{~kg}$ of household waste daily, followed by $30.0 \%$ that generate less than $2 \mathrm{~kg}$.

\begin{tabular}{|c|c|c|}
\hline Quantity of Waste & Frequency & Percentage \\
\hline Less than 2kg & 120 & 30.0 \\
\hline Between 3kg and 4kg & 199 & 50.0 \\
\hline Between 5kg and 6kg & 39 & 10.0 \\
\hline Above 6kg & 42 & 11.0 \\
\hline Total & 400 & 100.0 \\
\hline
\end{tabular}

Table 5: Distribution by Quantity of Waste Generated Each Day by Households 
Those generating between $5 \mathrm{~kg}-6 \mathrm{~kg}$ and above $6 \mathrm{~kg}$ consists of $10.0 \%$ and $11.0 \%$ respectively. This result is to be expected as it well established in the literature that household size composition is directly proportional to the quantity of waste generation (Ogwueleka 2003). This is because it is established in literature that in many northern part of Nigeria are often larger compared to other parts of the country. This is further confirmed in a report by Nigeria Child Labour Survey 2002/2001, which reported that Adamawa state have an average household size of 5.1 persons.

\subsection{Waste Sorting by Respondents}

Figure 2 reveals the percentage distribution of respondents who sort or do not sort their waste before disposals. Waste is sorted based on material specifications so as minimise the challenges of waste collection and recycling by waste managers. Domestic waste, when sorted and treated well, can be turned into a resource

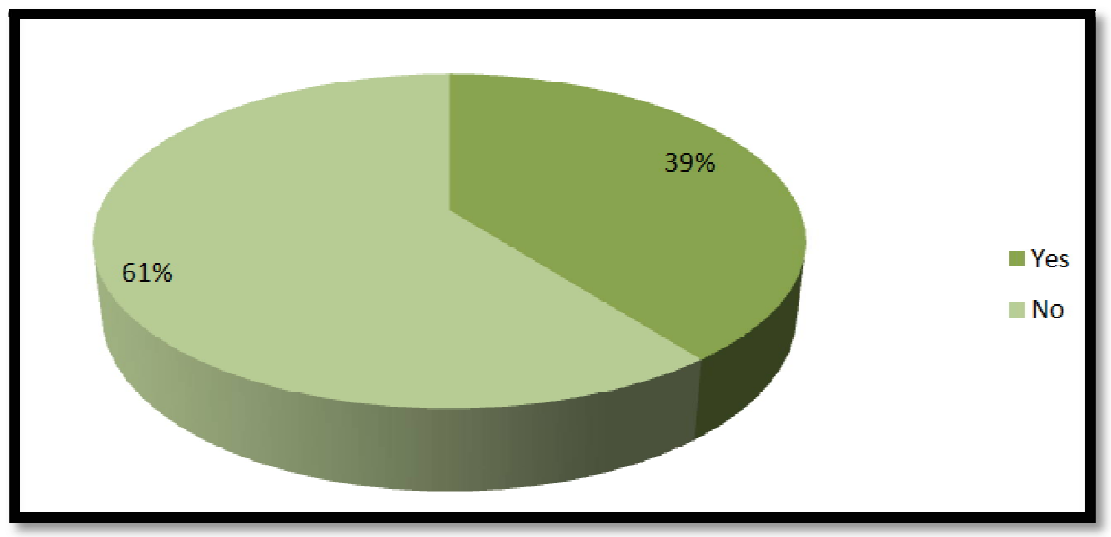

Figure 2: Percentage Distributions of Respondents on Whether They Sort Their Waste or Not Source: Field Survey, 2013

It is obvious from the data in Figure 2 that majority of the sampled women $(61 \%)$ do not sort their waste before disposing, whereas, about 39\% sort their wastes before it is disposed. This finding is supported by Ishaku, Majid and Roobiah (2011) who report that wastes in Adamawa state are neither sorted nor recycled but dumped in an open dump in and around major towns like Numan, Jimeta -Yola the state capital among others areas.

\subsection{Type of Waste Disposal Sites}

Table 6 shows the distribution of respondents on the types of waste disposal sites used for wastes disposals. From the data in Table 6, it reveals that about 38.2\% dump their wastes in open fields, while $41.8 \%$ dispose theirs at official designated dump sites.

\begin{tabular}{|c|c|c|}
\hline Type of Waste Disposal Sites & Frequency & Percentage \\
\hline Open field & 153 & 38.2 \\
\hline Dump site & 167 & 41.8 \\
\hline Pit & 26 & 6.5 \\
\hline Container & 40 & 10.0 \\
\hline Gutters & 4 & 1.0 \\
\hline Water ways & 10 & 2.5 \\
\hline Total & 400 & 100.0 \\
\hline
\end{tabular}

Table 6: Distribution of Responses on Types of Waste Disposal Sites

In addition, $6.5 \%, 10.0 \%, 1.0 \%$ and $2.5 \%$, dump theirs at pits, containers, gutters and water ways accordingly. By implication, it is clear to note that more than half of the entire sampled respondents dump their wastes indiscriminately either in open fields, gutters and or water ways. The result of this study shows that majority of the respondents violates the mandates given to owners, tenants and occupiers of any building which includes to keep clean the sidewalks, at least $45 \mathrm{~cm}$ from the sidewalk into the street along the building frontage, sides and back at all times. They are not to litter, sweep out or throw ashes, refuse, paper, nylon and rubbish into any street, public place or vacant plot in the area as noted by Alabi (2010).

\subsection{Preferred Waste Disposal Methods}

Table 7 shows the preferred waste disposal methods. From the analysis on the preferred waste disposal methods, $25.8 \%$ of the respondents prefer to bury their wastes in landfills pits, while $24.0 \%$ prefer burning/incineration methods. 


\begin{tabular}{|c|c|c|}
\hline Preferred Waste Disposal Methods & Frequency & Percentage \\
\hline Burying waste in landfill pits & 103 & 25.8 \\
\hline Burning/incineration waste & 96 & 24.0 \\
\hline Composting & 73 & 23.8 \\
\hline Recycling & 95 & 8.2 \\
\hline Open dumping & 33 & 100.0 \\
\hline Total & 400 & 18.2 \\
\hline
\end{tabular}

Table 7: Distribution of Respondents by the Preferred Waste Disposal Methods

On the other hand, $23.8 \%, 18.2 \%$ and $8.2 \%$ prefer recycling, composting and open dumping to be their waste disposal methods accordingly. Open dumping disposal system is ranked the least on the respondent's preferred method for waste disposal. This may not be unconnected with the finding made by Muttamara and Leong, (1996), which stated that the practice of open dumping of wastes often creates adverse environmental impacts, by not only threatening the health of the people nearby but also their immediate surroundings, which in turn affects their economic and social lives

\subsection{Challenges of Women to Domestic Waste Management Activities}

\subsubsection{Waste Dump Site Used Against the Preferred}

Domestic solid wastes are often times dumped either in secured (legal dump sites) or none secured dump sites (illegal dump sites). Figure 3 shows the distribution of respondents on types of waste dump site used as well astheir preferred type of waste dump sites. It is obvious from figure 3 that majority of respondents (55.8\%) dump their wastes in non-secured dump sites, followed by $28.2 \%$ who dump their wastes in secured points. Other categories of respondents use both secured and non-secured dump sites as their waste dump sites constitutes $16.0 \%$. The use both secured and none secured dump sites by $16.0 \%$ of the respondents may be due to locational conveniences, while the higher proportion of those who use non-secured dump sites may be used to account for the high incidence of indiscriminate dumping of refuse in the environment.

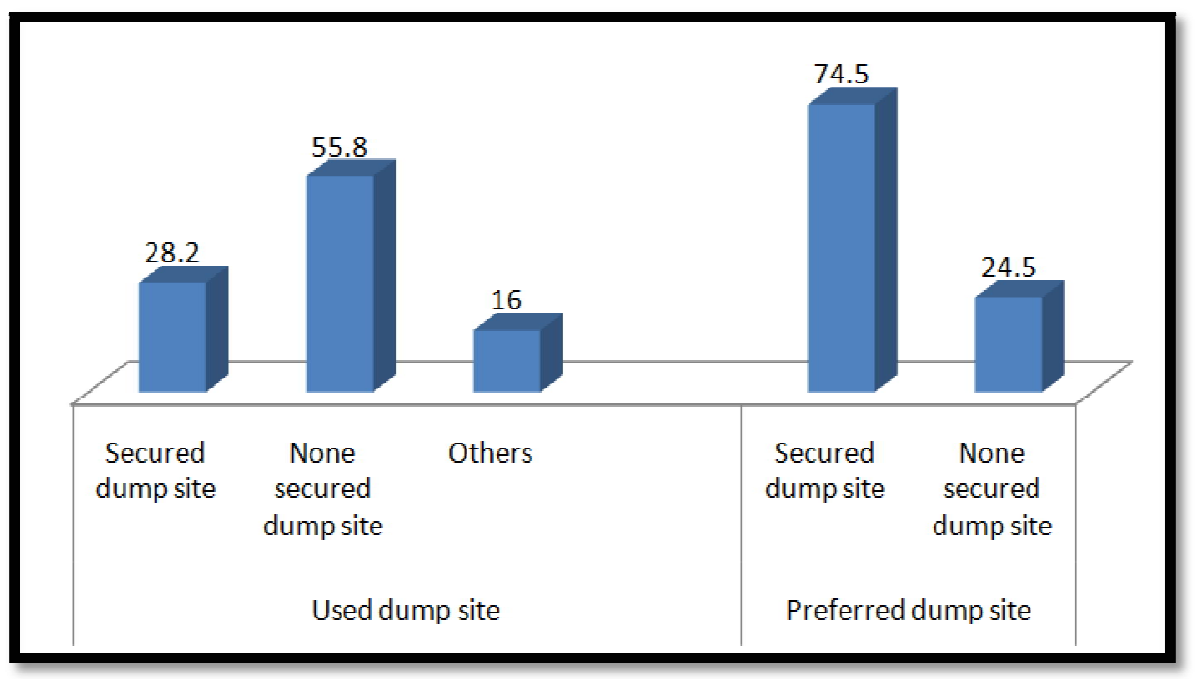

Figure 3: Percentage Distribution by Preferred Waste Dump Sites

In addition, about 1 out of 3 respondents preferred to use secured waste dump site as against those with preference for none secured disposal site. This is indicated where $74.5 \%$ prefer to use secured dump site, while $25.5 \%$ prefer none-secured dump sites. Sadly, it is obvious from the data that majority of the respondents prefers to use secured dump site to dispose their wastes, but due to the inadequacy/unavailability of their preferred dump site, many resorts to making use of none-secured sites and this may likely be responsible for the indiscriminate dumping of refuse on the environment which is affirmed in literature by Ishaku, Majid and Roobiah (2011) who reported that the problem of solid waste management in the state is becoming complicated as a result of indiscriminate dumping, rapid population growth and improper management practices leading to blockage of gutters/drainages, road access, as well as pollution of water, air and land which have a substantial negative effect on the environment and human health.

\subsection{Concerns of Women on Waste Management Collection Services}

Table 8 shows the respondent's concerns from the services rendered by the waste collectors in their respective areas. Among all the reasons given, low frequency of service $40.8 \%$ constitutes the dominant respondent's concerns from waste management service providers, followed by $23.6 \%$ who gave lack of clean appearance around the bin after collection of wastes by the waste collectors. 


\begin{tabular}{|c|c|c|}
\hline Response & Frequency & Percentage \\
\hline Unreliability of service & 116 & 18.5 \\
\hline Low frequency of service & 256 & 40.8 \\
\hline Lack of clean appearance around the bin after collection & 148 & 23.6 \\
\hline Waste collection bin located too far from the homes & 32 & 5.1 \\
\hline Waste not directly collected from the premises & 8 & 1.3 \\
\hline Lack of recycling practices & 20 & 3.2 \\
\hline Environmental concerns not taken into account & 36 & 5.7 \\
\hline Others & 12 & 1.9 \\
\hline Total & 400 & 100.0 \\
\hline
\end{tabular}

Table 8: Concerns of Respondents from Waste Management Collection Service

Unreliability of service is ranked third among the reasons with $18.5 \%$, whereas, environmental concerns not taken into account, location of waste collection bins far away from homes, non-recycling of waste and waste not being collected directly from the premises accounted for 5.7\%, 5.1\%, 3.2\% and 1.3\% of respondents reasons for dissatisfactions respectively. In the others category exorbitant/double charges from collectors, irregularity in collection hours accounted for $1.9 \%$ of the respondent's concerns with waste collection services providers. These reasons given may account for the high pile of wastes littering the environments in most parts of the state, as noted by Ishaku, Majid and Roobiah (2011) has noted that waste management practices in Adamawa state shows were faced with the problem of non-recycling and open dumping of waste in major towns like Numan and Jimeta-Yola. He went further to stress that the performance of ASEPA regarding waste management was below average as large tonnage of solid waste are seen at various locations of the state.

\subsection{Distances to Collection Points}

Table 9 shows the distribution of distance to waste collection points in meters and the perception of the distance by the respondents receiving waste management services. It is shown from the Table that majority of respondents $(36.3 \%)$ covers a distance of less than $100 \mathrm{~m}$ to disposal point and sees the distance as acceptable. While the least distance covered to waste disposal/collection point is above 500 meters and majority that constitutes $6.4 \%$ perceived the distance as unacceptable.

\begin{tabular}{|c|c|c|c|c|c|c|}
\hline \multirow{2}{*}{ Distance to Collection Point } & \multicolumn{4}{|c|}{ Perceptions } \\
\cline { 2 - 7 } & \multicolumn{2}{|c|}{ Acceptable } & \multicolumn{2}{c|}{ Unacceptable } & \multicolumn{2}{c|}{ Total } \\
\cline { 2 - 7 } & No. & $\mathbf{\%}$ & No. & $\mathbf{\%}$ & No. & \% \\
\hline$<100$ meters & 57 & 36.3 & 9 & 5.7 & 66 & 42.0 \\
\hline 150-300 Meters & 20 & 12.7 & 15 & 9.6 & 35 & 22.3 \\
\hline 350-500 Meters & 20 & 12.7 & 8 & 5.1 & 28 & 17.8 \\
\hline$>$ 500 Meters & 3 & 1.9 & 10 & 6.4 & 13 & 8.3 \\
\hline Don't know & 6 & 3.8 & 9 & 5.7 & 15 & 9.6 \\
\hline Total & 106 & 67.5 & 51 & 32.5 & 157 & 100.0 \\
\hline
\end{tabular}

Table 9: Distribution of Distance in Meters to Disposal Points and Perception of Distance by Respondents

Generally speaking, distance from households to the collection/disposal points seemed to play a prominent role in waste disposal process in the study area. A critical look at the Table shows that greater proportion of the respondents considers distances between less than 100 meters and 500 meters as acceptable, as compared to those who feel it as unacceptable. This is also supported by Poswa (2004) that the understanding of the mobility of households is paramount for the design of waste collection points. A gender sensitive waste service programme is the one that accommodates those family members who cannot leave their homes to dispose of waste at a distant waste collection points.

\section{Conclusion and Recommendations}

It is essential to identify and to integrate the roles of women in urban environmental management, especially in the aspect of sustaining environmental quality and in terms of waste management. This is so as in African many societies, women are mostly on the frontline of most household socio-economic activities, with their roles particularly pronounced in domestic activities, through which most domestic wastes are generated, managed and disposed. Hence need to incorporate their views and concerns on how to design, implement and effectively manage wastes cannot be overemphasized. It is therefore recommended that for there to be an effective waste management programmes and services, women should be strongly involved in solidarity networks, where they seek collective solutions for improving the environment. They should be found at the root of every initiative on health care, supply of drinking water or awareness about environmental sanitation and community women groups should exert pressure on the authorities to obtain representation for the most under privileged people with regards to waste management and other similar areas. 


\section{References}

i. Ahmed M.I (2007). Introduction to Environmental Problems and Management. Kano, Nigeria. Jamil Press.

ii. Akwa L. (2009). Women involvement in Environmental protection and Management, A case of Nasarawa State. Journal of Sustainable Development in Africa 10. No.4

iii. Alabi J. (2010). Nigeria and Environmental Sanitation. Retrieved from http://www.wondaz.com/list4101.

iv. Bennehs, G., Songsore, J., Nabila S.J. Amuzu A.T., Tutu K.A, and Yaugyuorn (1993). Environmental problem and urban household In Greater Accra Metropolitan Area (GAMA). M.A.C. Stockholm, Ghana.

v. Blight, G. E. and Mbande, C. M. (1994). Problems of Waste Management in Developing Areas. Paper read in the First Conference on Environmental Management Technology and Development held on 7 - 8 March, 1994, PP 33, 1 - 33, 8: Department of Constitutional Development (DCD) (1999). A Citizen Guide to Municipal Service Partnership.

vi. Business Dictionary (2014). Household Domestic Waste. Webfinance.inc. www.businessdictionary.com

vii. Chuwang B. Z., (1997). An Appraisal of Residential Refuse Management in The Makama Housing Upgrading Project, Bauchi Town. An Unpublished M.Sc., Thesis, Department of Geography and Planning, University of Jos.

viii. Conserve Africa (2013). Women and Natural Resources. Conserve Africa United Kingdom. www.conservafrica.org.uk.

ix. Dankelmann, I. and Davidson, J. (1998). Women and environment in the third world: Alliance for the future. England. Earthscan Publication Ltd., London in Association with IUCN

x. Enweze, C. (2000). Experience and strategy in the water supply and sanitation sector in Nigeria in proceedings of the governors seminar and donors conference on strategies for attracting investments to water supply and sanitation sector, Abuja, 1-4 February 2000, Federal Ministry of Water Resources, Abuja.

xi. Imam, A, Mohammed. B; Wilson, D. C., and Cheeseman, C. R. (2007). Solid Waste Management in Abuja, Nigeria. Waste Management 28 (2): 468 - 472.

xii. Jiggins J. (1994).Changing the Boundaries: Women Centered Perspectives on Population and the Environment. New York: Island press.

xiii. Moser O.N.C (1993). Gender Planning and Development: Theory, Practices and Training, Routledge, London.

xiv. Muttamara, S., and Leong S.T (1996). Environmental Monitoring and Impact Assessment of a Solid Waste Disposal Site. Environmental Monitoring and Assessment 48: pp 1-24.

xv. National Population Commission (NPC) (2006). Bureau of Statistics Population Figures. FGN.

xvi. Nigerian Child Labour Act (2000/2001). National Modular Child Labour Survey Nigeria. Federal Republic of Nigeria (FOS) International Labour Organization (ILO) and Statistical Information and Monitoring Programme on Child Labour (SIMPOC).

xvii. Ogunboye A.A. (2003). Institutional Framework for Managing Metropolitan Solid Waste. International Journal of Environmental Issues. I (2) Pg152 - 163.

xviii. Ogwueleka I. C (2001). Analysis of Carbon Solid Waste in Nsukka, Nigeria. Journal of Solid Waste Technology and Management 29(4) 239-246.

xix. Onu, B., Price, T., Surendran, S., and Ebie, S. (2001). Solid Waste Management: A Critique of Nigeria's Waste Management Policy. International Journal of Knowledge, Culture and Change Management, 11; 373-400.

xx. Poswa T.T (2004) The Importance of Gender in Waste Management Planning: A Challenge for Solid Waste Managers. Transformation Technologies Durban, South Africa.

xxi. United Nations Fourth Conference on Women (1995). Women and the Environment Diagnosis: Action for Equality, Development and Peace. Beijing, China.

xxii. Willson D.G., (2007). Handbook of Solid Waste management. New York. Van Nostrand Reinhold Company. 